J. Clin. Chem. Clin. Biochem.

Vol. 27, 1989, pp. 589-600

(C) 1989 Walter de Gruyter \& Co.

Berlin - New York

\title{
A Diagnostic Programme for Quantitative Analysis of Proteinuria
}

\author{
By W. Hofmann and W. G. Guder \\ Institut für Klinische Chemie, Städtisches Krankenhaus München Bogenhausen
}

(Received December 31, 1988/May 18, 1989)

Summary: A spectrum of quantitative methods was adapted to the Kone Specific Analyser for the purpose of recognizing, quantifying and differentiating various forms of proteinuria. Total protein, IgG, albumin and $\alpha_{1}$-microglobulin (measured by turbidimetry), $\mathrm{N}$-acetyl- $\beta-D$-glucosaminidase activity and creatinine (measured photometrically), were measured in undiluted urine; in addition $\alpha_{1}$-microglobulin was measured in serum.

Within and between run precision, accuracy and linearity of the turbidimetric methods were in good agreement with nephelometric procedures. All turbidimetric methods exhibited a correlation coefficient $r>0.98$ when compared with the radial immunodiffusion procedure as reference method. Total protein measured turbidimetrically with the Kone Specific Analyser was in good agreement with the manual biuret procedure.

The low detection limits and linearities allowed quantification of urine analytes from the lower range of normals up to ten times the upper limit of normals.

The measured analytes exhibited stability in urine at $\mathrm{pH} 4-8$ over at least seven days at $4-6^{\circ} \mathrm{C}$ and $-20^{\circ} \mathrm{C}$. Only IgG showed a significant loss (up to 30 percent), when measured after storage at $-20^{\circ} \mathrm{C}$.

Quantities per mol creatinine showed significantly lower intra-individual and inter-individual variability than quantities per liter. In 31 normal persons, the intraindividual variation was lowest for $N$-acetyl- $\beta$ - $D$-glucosaminidase activity (13\%) and highest for total protein (33\%), when measured in the second morning urine on 5 consecutive days.

When related to creatinine, results obtained in the second morning urine showed no significant differences from those in $24 \mathrm{~h}$ urine, except for $\alpha_{1}$-microglobulin which gave lower values in $24 \mathrm{~h}$ urines.

The upper normal limits, calculated as the $95 \%$ ranges, were determined from 154 urines of 31 individuals. Nearly all analytes showed an asymmetric distribution. Because of a wide tailing of the upper limit, preliminary upper normal limits were set above this range:

Total protein:

IgG:

Albumin:

$\alpha_{1}=$ Microglobulin:

$\mathrm{N}$-Acetyl- $\beta-D$-glucosaminidase:
$7.9 \mathrm{~g} / \mathrm{mol}$ creatinine ( $70 \mathrm{mg} / \mathrm{g}$ creatinine)

$1.13 \mathrm{~g} / \mathrm{mol}$ creatinine $(10 \mathrm{mg} / \mathrm{g}$ creatinine)

$2.26 \mathrm{~g} / \mathrm{mol}$ creatinine $(20 \mathrm{mg} / \mathrm{g}$ creatinine)

$1.58 \mathrm{~g} / \mathrm{mol}$ creatinine $(14 \mathrm{mg} / \mathrm{g}$ creatinine)

$0.56 \mathrm{kU} / \mathrm{mol}$ creatinine ( $5 \mathrm{U} / \mathrm{g}$ creatinine).

Application of the newly adapted programme to unselected urines sent for urine analysis revealed a threefold increase in the proportion of results outside the normal ranges, compared with the routinely used protein test strip procedure. All additional positive urines exhibited either signs of glomerular or tubular proteinuria. Determination of albumin or $\mathrm{N}$-acetyl- $\beta-D$-glucosaminidase excretion was sufficient to detect these additional cases. 


\section{Introduction}

Proteinuria is usually detected by qualitative tests based either on acid precipitation or on the test strip procedure, using the protein-error-of-indicator principle $(1,2)$. These tests, however, seem not to fulfil the medical requirements, since neither the detection limit nor the analytical specificity allow the recognition of all clinically relevant forms of proteinuria (3, 4). This is especially true of all kinds of prerenal proteinurias (i.e. Bence-Jones-, myoglobin-, haemoglobin-) and tubular proteinurias, as well as so-called microalbuminuria, all of which escape detection by the test strip procedure $(2-4)$. SDS-polyacrylamide gel electrophoresis (PAGE) was proposed to overcome this problem (5-7). In fact many more tubular proteinurias were detected when this technique was applied as a screening procedure $(3,7)$. In spite of its performance, this method has not found wide application as a routine procedure, because of its cost and time effectiveness. We therefore tried to find an alternative solution to this problem by combining quantitative techniques for the measurement of single urinary proteins of different molecular weights with established procedures for a tubular enzyme, creatinine and total protein $(8,9)$. The aim of the present diagnostic programme was to exclude, quantify and differentiate various forms of proteinuria in a single automated programme, which can be applied to undiluted urine samples. The present methodology has already been partially presented in a preliminary form (10).

\section{Materials and Methods}

Urine samples

Urine samples $(10 \mathrm{ml})$ were collected in closed polystyrene vials (Greiner, Nürtingen, FRG). Preliminary reference ranges were established from 154 second morning urines, voided between 8 and 10 a.m. by 31 persons aged $18-60$ years (12 men, 19 women) who had no anamnestic or clinical symptoms, and no signs of renal or other diseases. Twenty four-hour urines were also collected from 13 normals. The blood pressure of this reference population was below $140 / 90 \mathrm{mmHg}$.

In addition 67 urines were taken from the single daily routine of all surgical and medical departments of the Bogenhausen City Hospital.

All urines were tested with an automated test strip procedure (Rapimat II, Behringwerke AG, Marburg, FRG) and found to be negative in the reference population. The test strip programme included protein, nitrite, glucose, leukocytes, blood and $\mathrm{pH}$. All subsequent procedures were performed with supernatant urines after centrifugation for $10 \mathrm{~min}$ at $800 \mathrm{~g}$ on the same day. For stability studies urine supernatants were stored at $4-6^{\circ} \mathrm{C}$ in the cool room and/or at $-20^{\circ} \mathrm{C}$ in the deep freezer.

\section{Analytical procedures}

Table 1 summarizes the parameters for adaptation of the following procedures to the Kone Specific Analyser (KONE, Turku, Finnland).

\section{Total protein}

Protein was determined by the turbidimetric endpoint procedure of Cheung et al. (9), using $0.18 \mathrm{~mol} / 1$ trichloroacetic acid and $0.34 \mathrm{~mol} / 1$ hydrochloric acid (Merck, Darmstadt, FRG). Undiluted urine $(50 \mu \mathrm{l})$ was added to $150 \mu$ l of trichloroacetic acid (reagent 1 ) and the turbidity signal compared with that of parallel sample using $\mathrm{HCl}$ as reagent 1 . The difference was compared with that for the standard dilution of a control serum (Kontrollogen ${ }^{\circledR}$, Product No. 623118, Behringwerke AG, Marburg, FRG), diluted $1: 100$ with $155 \mathrm{mmol} / 1 \mathrm{NaCl}$. The standard protein concentration (biuret procedure) was $540 \mathrm{mg} / \mathrm{l}$, resulting in a factor of 2763 .

The biuret reaction after precipitation with trichloroacetic acid (11) was used as the comparison method.

\section{Immunoglobulin $G$}

IgG was determined turbidimetrically using the polyethyleneglycol buffer (Product No. D-365, OA1) (reagent I) and anti human IgG serum (reagent II) of Orion Diagnostica, Helsinki, Finland (Product No. 67412/OB2). Calibrator LC-V (Behringwerke AG, Marburg, FRG) was used as standard. A calibration

Tab. 1. Instrumental settings for determination of the urine analytes on the Kone Specific Analyser.

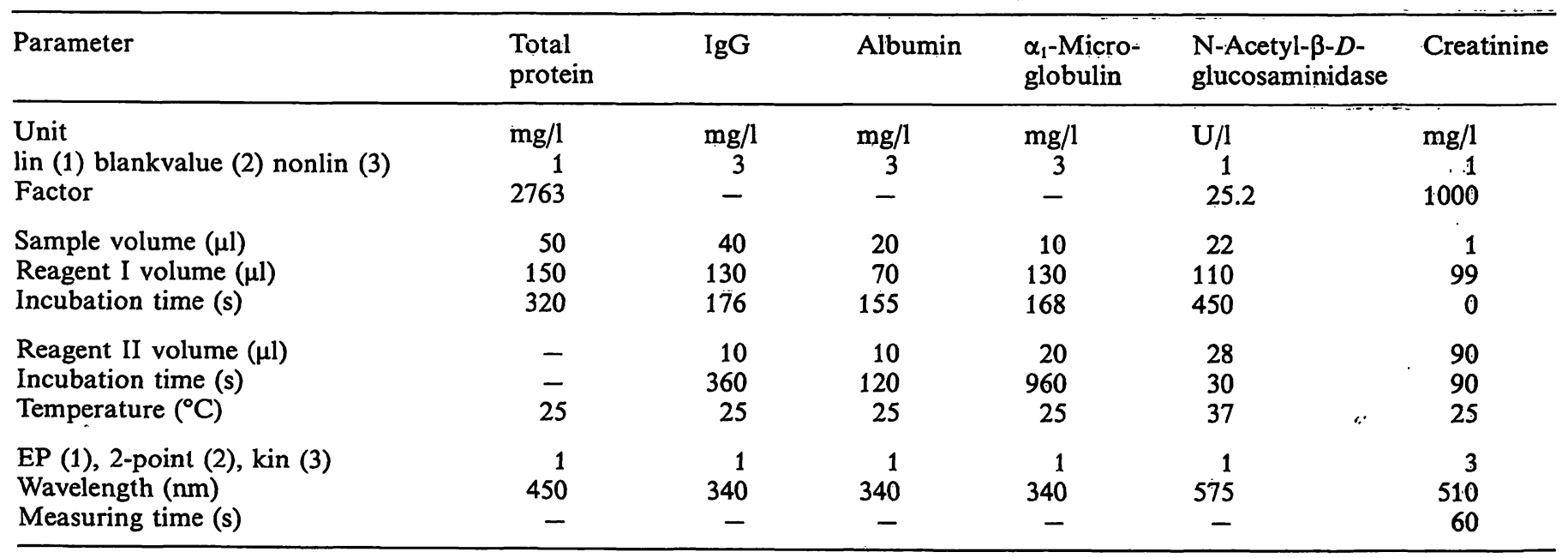


curve was constructed using concentrations of $1,3,10,30$ and $100 \mathrm{mg} / \mathrm{l}$ respectively by dilution of the standard with 155 $\mathrm{mmol} / \mathrm{I} \mathrm{NaCl}$. Radial immunodiffusion (IgG LC, Behringwerke AG, Marburg, FRG) was used as the comparison method.

\section{Albumin}

Albumin was measured turbidimetrically as described earlier (12) using polyethyleneglycol (reagent 1) and anti human albumin (reagent 2) from Orion Diagnostica (Helsinki, Finnland, Product No. D748/ND1). The instrumental settings taken from the previous publication are summarized for comparison in table 1. Radial immunodiffusion served as the comparison method (albumin VLC, Behringwerke AG, Marburg, FRG).

\section{$\alpha_{1}-$ Microglobulin}

The procedure for quantifying $\alpha_{1}$-microglobulin was also adapted by using polyethylene glycol (reagent 1) from Orion Diagnostica (Helsinki, Finland) and anti human $\alpha_{1}$-microglobulin (reagent 2) from DaKoPatts, Kopenhagen, Denmark (Product No. A256/013). For preparation of the standard curve, a protein standard urine concentrate (Product No. DUUM 02/ 03/049802M, Behringwerke AG, Marburg, FRG), calibrated by radial immunodiffusion, was diluted to concentrations of 7 , $14,28,57,114 \mathrm{mg} / \mathrm{l}$.

Radial immunodiffusion (Behringwerke AG, Marburg, FRG) was used as the comparison method. $\alpha_{1}$-Microglobulin in serum was measured with the same analytical programme by diluting sera $1: 10$ with $155 \mathrm{mmol} / \mathrm{l} \mathrm{NaCl}$.

\section{$N$-acetyl- $\beta$-D-glucosaminidase ${ }^{1}$ )}

The tubular enzyme activity was measured with 3-cresolsulphonephthaleinyl-N-acetyl- $\beta$ - $D$-glucosaminide (13), using a test kit purchased by Boehringer, Mannheim, FRG. Urine $(22 \mu \mathrm{l})$ was mixed with $110 \mu \mathrm{l}$ reagent 1 consisting of $2.75 \mathrm{mmol} / \mathrm{l}$ substrate and $3.07 \mathrm{mmol} / 1$ borax in $50 \mathrm{mmol} / \mathrm{l}$ potassium citrate buffer, $\mathrm{pH}$ 4.75. After $450 \mathrm{~s}$ incubation at $37^{\circ} \mathrm{C}$ the reaction was stopped with $28 \mu \mathrm{l} \mathrm{Na} \mathrm{CO}_{3}(1.5 \mathrm{~mol} / \mathrm{l})$ and the absorbance read at $575 \mathrm{~nm}$ after an additional $30 \mathrm{~s}$. A reagent blank was run in each series using $\mathrm{H}_{2} \mathrm{O}$ as sample. This blank value was substracted from all samples. The factor was calculated using the molar lineic absorbance of $4070 \mathrm{~m}^{2} \cdot \mathrm{mol}^{-1}$ for the reaction product under the chosen conditions. This method was compared with the manual procedure and with the method employing sample preparation as described by Maruhn et al. $(8,14)$. The manual procedure was also compared with the Epos Analyser (Eppendorf, Hamburg, FRG) adaptation published previously (8).

\section{Creatinine in urine}

Creatinine was measured with the kinetic Jaffé reaction adapted to the Kone Specific Analyser with undiluted urine, using the reagents prepared for the mechanised version on Hitachi 705 (Boehringer, Mannheim, FRG). Urine $(1 \mu \mathrm{l})$ was mixed with $99 \mu \mathrm{l}$ picric acid reagent (reagent 1) and $90 \mu \mathrm{l} \mathrm{NaOH}$ (reagent 2) and the absorbance at $510 \mathrm{~nm}$ was read after $90 \mathrm{~s}$ of incubation at $25^{\circ} \mathrm{C}$ using the kinetic mode over $60 \mathrm{~s}$. This method was compared with the automated procedure adapted to the Hitachi 705 using 1:20 diluted urine samples.

\section{Control materials}

Intra-assay and inter-assay precision were determined with Precipath U (Boehringer, Mannheim, F F RG) diluted with 155 $\mathrm{mmol} / \mathrm{l} \mathrm{NaCl}$ (total protein, IgG, albumin), protein standard urine concentrate (Behringwerke AG, Marburg, FRG) $\left(\alpha_{1}\right.$-mi-

') Enzyme: N-acetyl- $\beta$ - $D$-glucosaminidase (EC 3.2.1.30) croglobulin), $\mathrm{N}$-acetyl-glucosaminidase standard (Boehringer, Mannheim, FRG) (N-acetyl- $\beta$ - $D$-glucosaminidase) and Urichem (Urine Chemistry Control, Human Level II) (Fisher Scientific, Orangenburg, NY, USA). Accuracy was measured with Spinal Fluid Control, Pool 1.50 (Fisher Scientific, Orangenburg, NY, USA), Precipath U (Boehringer, Mannheim, FRG) and Hitachi-calibrator (Boehringer, Mannheim, FRG), diluted $1: 100$ with $155 \mathrm{mmol} / 1 \mathrm{NaCl}$ (total protein), Seroquant (Behringwerke AG, Marburg, FRG) and Precipath $U$ (Boehringer, Mannheim, FRG), diluted $1: 200$ with $155 \mathrm{mmol} / \mathrm{l} \mathrm{NaCl}$ (IgG), Spinal Fluid Control, diluted $1: 2$ and Kontrollogen LP (Behringwerke AG, Marburg, FRG), diluted $1: 200$ with $155 \mathrm{mmol} / \mathrm{l}$ $\mathrm{NaCl}$ (albumin). No materials with target values were available for $\alpha_{1}$-microglobulin and $N$-acetyl- $\beta$ - $D$-glucosaminidase.

\section{Statistical evaluation}

Analytical intra-assay and inter-assay precision were calculated as described by Keller (15).

The procedure to quantify intra- and inter-individual variability described by Keller (15) for normal distributed values was modified for non-normal distributed results. For the calculation of the intra-individual variability, samples voided on 5 consecutive days from each of 31 normal persons were used. Individual variability was calculated from the equation:

$$
\begin{aligned}
& \text { intraindividual variability }=\frac{\frac{\Sigma(x-\tilde{\mathbf{x}})}{\mathrm{n}}}{\tilde{\mathbf{x}}} \times 100, \\
& \text { where } \\
& \mathbf{x}=\text { measured individual value, } \\
& \mathbf{n}=\text { number of independent samples, } \\
& \tilde{\mathbf{x}}=\text { median of results of one individual. }
\end{aligned}
$$

For the calculation of inter-individual variability one day of 5 was selected at random and the results for that day analysed as described above. Preliminary reference ranges were independently derived from the results of 154 urines of 31 individuals by determination of the 95 percentile.

Statistical significance was tested by the paired signed rank test of Wilcoxon, Mann \& Whitney (16). Linear regression analysis was performed using the least square analysis method (16). In addition, the general regression procedure described by Bablok et al. was applied using the MS-DOS program version provided by these authors (17).

\section{Results}

\section{Adaptation of methods}

The aim of the present study was to adapt a combination of turbidimetric and kinetic photometric procedures at $25^{\circ} \mathrm{C}$, and an enzyme activity determination at $37^{\circ} \mathrm{C}$ to a single analyser. Using the settings summarized in table 1 this was realised on a Kone Specific Analyser. Twenty five undiluted urine samples can be performed in 1 hour. As shown in table 2 the detection limits were in the lower normal range for $\operatorname{IgG}(1 \mathrm{mg} / \mathrm{l})$ and albumin $(4 \mathrm{mg} / \mathrm{l})$, while the detection limits for total protein and $\mathrm{N}$-acetyl- $\beta$ - $D$-glucosaminidase were $10 \mathrm{mg} / \mathrm{l}$ and $1 \mathrm{U} / \mathrm{l}$ respectively. Linearity was obtained up to a concentration ten times the upper normal limit. To exclude antigen excess as a possible source of error, test strip positive samples 
Tab.2. Detection and linearity limits of the methods used to measure urine analytes.

\begin{tabular}{|c|c|c|c|c|c|c|}
\hline $\begin{array}{l}\text { Analyte } \\
\text { Unit }\end{array}$ & $\begin{array}{l}\text { Total } \\
\text { Protein } \\
\mathrm{mg} / 1\end{array}$ & $\begin{array}{l}\text { IgG } \\
\mathrm{mg} / 1\end{array}$ & $\begin{array}{l}\text { Albumin } \\
\mathrm{mg} / \mathrm{l}\end{array}$ & $\begin{array}{l}\alpha_{1} \text {-Micro- } \\
\text { globulin } \\
\mathrm{mg} / 1\end{array}$ & $\begin{array}{l}N \text {-Acetyl- } \beta-D \text { - } \\
\text { glucosaminidase } \\
U / 1\end{array}$ & $\begin{array}{l}\text { Creatinine } \\
\mathrm{mmol} / \mathrm{l}\end{array}$ \\
\hline $\begin{array}{l}\text { Detection limit } \\
\text { Linearity limit }\end{array}$ & $\begin{array}{r}10 \\
4500\end{array}$ & $100^{1.0}$ & $\begin{array}{l}4.0 \\
350\end{array}$ & $\begin{array}{l}1.0 \\
114^{1.0}\end{array}$ & 60 & $\begin{array}{l}0.09 \\
44.9\end{array}$ \\
\hline
\end{tabular}

with a total protein concentration above $300 \mathrm{mg} / 1$ were also measured in a $1: 10$ dilution with $155 \mathrm{mmol} / \mathrm{l}$ $\mathrm{NaCl}$. At protein concentrations above $4500 \mathrm{mg} / \mathrm{l} \mathrm{a}$ dilution of $1: 20$ had to be applied. The recovery of standards diluted in this way was between $95-105 \%$ for all proteins measured.

\section{Analytical precision and accuracy}

The intra-assay and inter-assay precisions are summarized in table 3.

Intra- and inter-assay precision for the proteins were in the usual range for automated nephelometric procedures, i. e. between 2.5 and $11.8 \%$. Intra-assay variation for $\mathrm{N}$-acetyl- $\beta$ - $D$-glucosaminidase was less than $4 \%$, and inter-assay precision slightly higher. CV's at the upper normal level were about twice as high as those in the pathological range.

Accuracies measured with various control materials are summarized in table 4 . The deviation was between 1 and $13 \%$ for total protein, IgG and albumin, i.e. no higher than the two-fold standard deviation of day to day precision, although the methods used for determination of the target values were not the same. No materials with target values were available for $\alpha_{1-}$ microglobulin and $\mathrm{N}$-acetyl- $\beta$ - $D$-glucosaminidase activity.

\section{Correlation with comparison methods}

Figure 1 compares the results for the analysis of unselected urines, using established standard methods and using the present method. In general, the linearity of the present method exceeded that of the comparison method with no significant deviation of the results. Conversion factors were between 0.92 and 1.11, independent of the regression formula applied (17), with correlation coefficients between 0.980 and 0.994 .

The $\mathrm{N}$-acetyl- $\beta-D$-glucosaminidase method of Noto et al. (13), where gel filtration of urine to remove inhibitors is not necessary, showed a good correlation with the method of Maruhn (14) $(r=0.994)$. The activities measured with the Kone Specific Analyșer (or Epos Analyser), however, were almost only half of those obtained by the method of Maruhn.

Tab. 3. Analytical precision of automated procedures for urine analytes.

\begin{tabular}{|c|c|c|c|c|c|c|c|}
\hline \multirow[t]{2}{*}{ Analyte } & \multirow[t]{2}{*}{$\mathbf{N}$} & \multicolumn{3}{|c|}{ Within run } & \multicolumn{3}{|c|}{ Between rụn } \\
\hline & & Mean & SD & $\begin{array}{l}\mathrm{CV} \\
(\%)\end{array}$ & Mean & SD & $\begin{array}{l}\mathrm{CV} \\
(\%)\end{array}$ \\
\hline Total protein (mg/l) & $\begin{array}{l}20 \\
20 \\
20\end{array}$ & $\begin{array}{r}2846.0 \\
188.0 \\
31.1\end{array}$ & $\begin{array}{r}74.9 \\
6.0 \\
3.7\end{array}$ & $\begin{array}{r}2.6 \\
3.2 \\
11.8\end{array}$ & $\begin{array}{r}2660.0 \\
172.0 \\
26.0\end{array}$ & $\begin{array}{r}64.0 \\
6.2 \\
4.1\end{array}$ & $\begin{array}{r}2.4 \\
3.6 \\
15.6\end{array}$ \\
\hline $\operatorname{IgG}(\mathrm{mg} / \mathrm{l})$ & $\begin{array}{l}20 \\
20 \\
20\end{array}$ & $\begin{array}{r}103.4 \\
9.8 \\
3.2\end{array}$ & $\begin{array}{l}2.8 \\
0.3 \\
0.1\end{array}$ & $\begin{array}{l}2.7 \\
3.1 \\
4.2\end{array}$ & $\begin{array}{r}113.7 \\
10.5 \\
3.5\end{array}$ & $\begin{array}{l}4.1 \\
0.8 \\
0.4\end{array}$ & $\begin{array}{r}3.6 \\
7.5 \\
10.5\end{array}$ \\
\hline Albumin (mg/l) & $\begin{array}{l}20 \\
20 \\
20\end{array}$ & $\begin{array}{r}202.4 \\
26.4 \\
10.6\end{array}$ & $\begin{array}{r}11.7 \\
0.8 \\
0.3\end{array}$ & $\begin{array}{l}5.8 \\
3.0 \\
2.5\end{array}$ & $\begin{array}{r}236.0 \\
24.8 \\
9.3\end{array}$ & $\begin{array}{l}9.3 \\
1.2 \\
0.7\end{array}$ & $\begin{array}{l}3.9 \\
4.8 \\
7.2\end{array}$ \\
\hline$\alpha_{1}$-Microglobulin $(\mathrm{mg} / \mathrm{l})$ & $\begin{array}{l}20 \\
20 \\
20\end{array}$ & $\begin{array}{r}118.0 \\
14.7 \\
7.0\end{array}$ & $\begin{array}{l}3.5 \\
0.6 \\
0.4\end{array}$ & $\begin{array}{l}2.9 \\
4.2 \\
6.0\end{array}$ & $\begin{array}{r}142.1 \\
15.5 \\
7.2\end{array}$ & $\begin{array}{l}4.8 \\
1.2 \\
0.8\end{array}$ & $\begin{array}{r}3.4 \\
7.8 \\
10.7\end{array}$ \\
\hline $\begin{array}{l}\mathrm{N} \text {-Acetyl- } \beta \text { - } D \text {-glucosaminidase }(\mathrm{U} / \mathrm{l}) \\
\end{array}$ & $\begin{array}{l}20 \\
20 \\
20\end{array}$ & $\begin{array}{r}19.6 \\
6.0 \\
1.9\end{array}$ & $\begin{array}{l}0.2 \\
0.1 \\
0.1\end{array}$ & $\begin{array}{l}1.1 \\
1.8 \\
3.8\end{array}$ & $\begin{array}{r}20.0 \\
6.2 \\
2.4\end{array}$ & $\begin{array}{r}0.8 \\
0.3 \\
\therefore \quad 0.2\end{array}$ & $\begin{array}{l}4.2 \\
4.8 \\
7.1\end{array}$ \\
\hline Creatinine (mmol/l) & $\begin{array}{l}20 \\
20 \\
20\end{array}$ & $\begin{array}{r}16.9 \\
8.0 \\
1.6\end{array}$ & $\begin{array}{l}0.3 \\
0.2 \\
0.1\end{array}$ & $\begin{array}{l}2.0 \\
2.9 \\
4.5\end{array}$ & $\begin{array}{r}16.1 \\
7.9 \\
1.6\end{array}$ & $\begin{array}{l}0.6 \\
0.3 \\
0.1\end{array}$ & $\begin{array}{l}3.7 \\
3.8 \\
6.3\end{array}$ \\
\hline
\end{tabular}


Tab. 4. Accuracy of automated procedures for urine analytes.

\begin{tabular}{|c|c|c|c|c|c|c|}
\hline Analyte & Material & Method used for target value & $\begin{array}{l}\text { Target } \\
\text { value } \\
\mathrm{mg} / 1\end{array}$ & $\begin{array}{l}\text { Result } \\
\mathrm{mg} / 1\end{array}$ & $\begin{array}{l}\text { Difference } \\
\mathrm{mg} / \mathrm{l}\end{array}$ & $\begin{array}{l}\text { Deviation } \\
\%\end{array}$ \\
\hline Total protein & $\begin{array}{l}\text { Spinal Fluid Control } \\
\text { Precipath U }(1: 100) \\
\text { Hitachi Cal. }(1: 100)\end{array}$ & $\begin{array}{l}\text { Trichloroacetic acid } 30 ; 125 \mathrm{~g} / 1 \\
\text { Biuret } \\
\text { Biuret }\end{array}$ & $\begin{array}{l}570 \\
575 \\
520\end{array}$ & $\begin{array}{l}588 \\
571 \\
532\end{array}$ & $\begin{array}{r}18 \\
4 \\
12\end{array}$ & $\begin{array}{l}+3.2 \\
-0.7 \\
+\quad 2.3\end{array}$ \\
\hline IgG & $\begin{array}{l}\text { Seroquant }(1: 200) \\
\text { Precipath U }(1: 200)\end{array}$ & $\begin{array}{l}\text { RID } \\
\text { turbidimetric }\end{array}$ & $\begin{array}{l}61 \\
45\end{array}$ & $\begin{array}{l}63 \\
51\end{array}$ & $\begin{array}{l}2 \\
6\end{array}$ & $\begin{array}{l}+3.3 \\
+13.3\end{array}$ \\
\hline Albumin & $\begin{array}{l}\text { Spinal Fluid Control }(1: 2) \\
\text { Kontrollogen LP }(1: 200) \\
\text { Beckman Cal. }(1: 200)\end{array}$ & $\begin{array}{l}\text { electrophoretic* } \\
\text { Bromocresylgreen } \\
\text { nephelometric }\end{array}$ & $\begin{array}{l}197 \\
200 \\
210\end{array}$ & $\begin{array}{l}206 \\
205 \\
211\end{array}$ & $\begin{array}{l}9 \\
5 \\
1\end{array}$ & $\begin{array}{l}+4.6 \\
+2.5 \\
+0.5\end{array}$ \\
\hline
\end{tabular}

* electrophoretic analysis (agarose gel), calculation based upon a total protein of $580 \mathrm{mg} / \mathrm{l}$

\section{Stability of urine analytes}

The stability of the urine analytes was measured at $4^{\circ} \mathrm{C}$ and $-20^{\circ} \mathrm{C}$ over 20 days. No significant changes were found for albumin and $\alpha_{1}$-microglobulin (18) over 7 days at $4{ }^{\circ} \mathrm{C}$ and 20 days at $-20^{\circ} \mathrm{C}$. In accordance with previous reports of others (19), Nacetyl- $\beta-D$-glucosaminidase activity was stable over more than 7 days at both temperatures. Only IgG showed a decrease (up to $30 \%$ ), when measured in samples stored frozen, whereas no change was found at $4{ }^{\circ} \mathrm{C}(18)$. Samples were therefore stored at $4-6{ }^{\circ} \mathrm{C}$ for up to 7 days, if determinations were not performed on the same day.

\section{Biological variability and reference ranges}

The biological variability calculated from second morning urines on 5 consecutive days was studied in 31 normal persons. The intra- and inter-individual biological variabilities obtained are summarized in table 5. It can be seen that the biological inter- and intra-individual variability were much lower if the

Tab. 5. Biological variability of analytes in urine.

\begin{tabular}{|c|c|c|c|c|}
\hline & \multicolumn{2}{|c|}{$\begin{array}{l}\text { Intra-individual } \\
(\%)\end{array}$} & \multicolumn{2}{|c|}{$\begin{array}{l}\text { Inter-individual } \\
(\%)\end{array}$} \\
\hline & per 1 & $\begin{array}{l}\text { per mol } \\
\text { creatinine }\end{array}$ & per 1 & $\begin{array}{l}\text { per mol } \\
\text { creatinine }\end{array}$ \\
\hline Total protein & 36 & 33 & 71 & 72 \\
\hline $\mathrm{IgG}$ & 29 & 25 & 69 & 44 \\
\hline Albumin & 29 & 22 & 71 & 43 \\
\hline$\alpha_{1}-$ Microglobulin & 26 & 20 & 71 & 44 \\
\hline $\begin{array}{l}\text { N-Acetyl- } \beta-D- \\
\text { glucosaminidase }\end{array}$ & 16 & 13 & 36 & 29 \\
\hline Creatinine & 20 & & 50 & \\
\hline
\end{tabular}

Intra- und inter-individual variabilities were calculated as described in the methods section. The results given represent the means of deviation as percent of the median of all determinations. values were related to creatinine. Inter-individual variability was between 1.8 and 2.2 times higher than intra-individual variability. $\mathrm{N}$-Acetyl- $\beta$ - $D$-glucosaminidase exhibited the lowest biological variability, followed by $\alpha_{1}$-microglobulin, albumin, IgG and total protein.

The preliminary $95 \%$ limits were:

\section{second morning urine}

total protein:

$6.3 \mathrm{~g} / \mathrm{mol}$ creatinine $(55.7 \mathrm{mg} / \mathrm{g}$ creatinine $)$

IgG:

$0.77 \mathrm{~g} / \mathrm{mol}$ creatinine $(6.8 \mathrm{mg} / \mathrm{g}$ creatinine $)$

albumin:

$1.34 \mathrm{~g} / \mathrm{mol}$ creatinine $(11.8 \mathrm{mg} / \mathrm{g}$ creatinine $)$

$\alpha_{1}$-microglobulin:

$1.49 \mathrm{~g} / \mathrm{mol}$ creatinine $(13.2 \mathrm{mg} / \mathrm{g}$ creatinine)

$\mathrm{N}$-acetyl- $\beta$ - $D$-glucosaminidase:

$0.47 \mathrm{kU} / \mathrm{mol}$ creatinine ( $4.2 \mathrm{U} / \mathrm{g}$ creatinine)

serum

$\alpha_{1}$-microglobulin:

$25-100 \mathrm{mg} / \mathrm{l}$.

Because nearly all analytes showed an asymmetric distribution pattern with a tailing (fig. 2), a somewhat higher "normal" limit is suggested

total protein:

$7.9 \mathrm{~g} / \mathrm{mol}$ creatinine $(70 \mathrm{mg} / \mathrm{g}$ creatinine)

IgG:

$1.13 \mathrm{~g} / \mathrm{mol}$ creatinine $(10 \mathrm{mg} / \mathrm{g}$ creatinine)

albumin:

$2.26 \mathrm{~g} / \mathrm{mol}$ creatinine $(20 \mathrm{mg} / \mathrm{g}$ creatinine) 

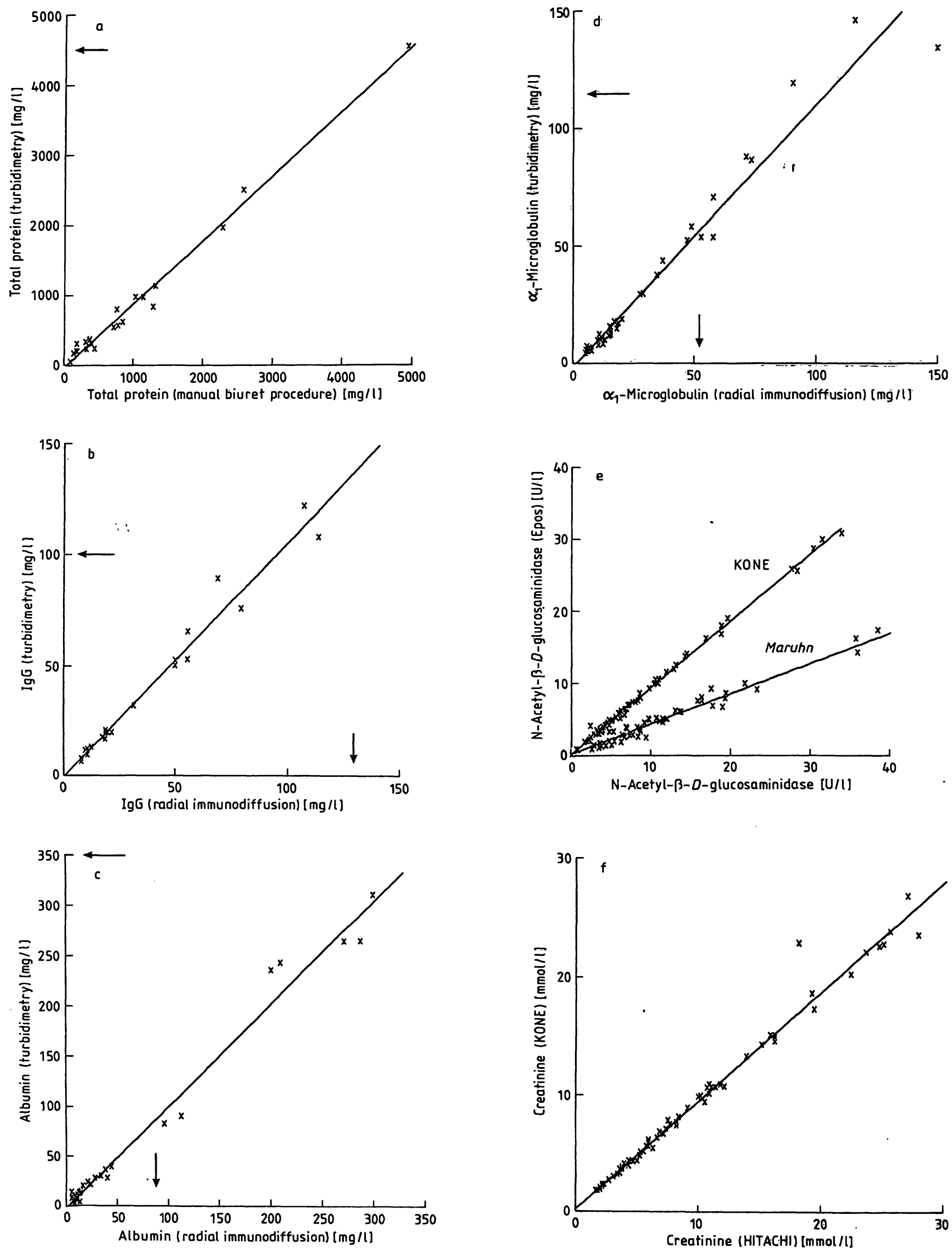

Fig. 1. Comparison of results from the present analytical procedures with those from established comparison methods.

20-74 unselected urines were analysed with the present programme and with the comparison methods (in brackets). Linear regression was calculated by the method of least squares (16) and by the method of Bablok et al. (17). The arrows indicate the concentration at which samples were diluted. 
$\alpha_{1}$-microglobulin:

$1.58 \mathrm{~g} / \mathrm{mol}$ creatinine (14 $\mathrm{mg} / \mathrm{g}$ creatinine)

$\mathrm{N}$-acetyl- $\beta$ - $D$-glucosaminidase:

$0.56 \mathrm{kU} / \mathrm{mol}$ creatinine ( $5 \mathrm{U} / \mathrm{g}$ creatinine).

No significant differences were observed between males and females.

Comparison between second morning urine and 24 hour urine

In view of the large variability of urine composition, the present parameters were measured in normal persons in spontaneous urine samples (second morning urine voided between $8-10 \mathrm{a} . \mathrm{m}$.) and the results compared with those from a 24 hour urine sample collected on the same day.

Table 6 summarizes the results obtained in 13 normal persons.

When tested with the paired signed rank test of Wilcoxon, Mann \& Whitney (16) no significant differences between analyte concentrations in second morning urine and $24 \mathrm{~h}$ urines were found for total protein, IgG and albumin, whereas $\alpha_{1}$-microglobulin and $\mathrm{N}$ acetyl- $\beta-D$-glucosaminidase activity exhibited significant differences.

When related to creatinine the differences between the two urines were no longer significant except in the case of $\alpha_{1}$-microglobulin.

Use of the new diagnostic program as screening procedure

In order to test the diagnostic utility of the present programme, 67 unselected urines from a daily routine were analysed and the results compared with the results of the usual test strip procedure. The results are summarized in table $7 \mathrm{a}, \mathrm{bc}$. As can be seen, 13 out of $67(19 \%)$ gave a positive test strip result for proteinuria. When analysed with the present analytical programme, 37 out ot 67 urines $(55 \%)$ gave at least one result outside the normal range. All five assays revealed nearly the same number of positive answers. Of the 28 urines with an elevated albumin only 12 gave a positive test strip result for protein. Of these 28 urines, 25 exhibited a simultanous elevation of IgG, 21 of $\alpha_{1}$-microglobulin and 20 of $\mathrm{N}$ acetyl- $\beta$ - $D$-glucosaminidase. Total protein was elevated together with albumin in 24 out of 28 urines.

Twenty eight urines showed an elevated $\mathrm{N}$-acetyl- $\beta$ $D$-glucosaminidase activity. All the other analytes were also elevated in $71-76 \%$ of these urines. Only $36 \%$ of the urines showing increased $N$-acetyl- $\beta-D$ glucosaminidase gave a positive protein test strip result.

When albumin and $\mathrm{N}$-acetyl- $\beta-D$-glucosaminidase were combined, 36 urines exhibited at least one positive result outside the normal range. This combination provided the highest rate of recognition of glomerular and tubular dysfunction. In comparison, only 33 urines exhibited an elevation of total protein and/or $\mathrm{N}$-acetyl- $\beta$ - $D$-glucosaminidase, 33 showed an elevation of albumin and/or $\alpha_{1}$-microglobulin, and 30 showed an elevation of total protein and/or albumin. The number for other combinations was less than 30 .

In order to test the diagnostic utility of the present programme for excluding haematuria and leukocyturia, the results were compared with those of the respective test strip field (tab. $7 \mathrm{c})$.

Eighteen urines were positive for the blood test strip. In 17 of these urines IgG was elevated. Similarly high numbers of positives were found for total protein and albumin. a. total protein (manual biuret procedure)
linear regression:
$\mathrm{n}=22 ; \mathrm{r}=0.994$
$y=-35+0.92 x$
Bablok et al.:
$y=-41+0.93 x$

b. IgG (radial immunodiffusion method)

$\begin{array}{ll}\text { linear regression: } & \mathrm{n}=20 ; \mathrm{r}=0.986 \\ \text { Bablok et al.: } & \mathrm{y}=-0.6+1.07 \mathrm{x} \\ & \mathrm{y}=-1.1+1.08 \mathrm{x}\end{array}$

c. albumin (radial immunodiffusion method)

$\begin{array}{ll}\text { linear regression: } & \mathrm{n}=30 ; \mathrm{r}=0.992 \\ & \mathrm{y}=-1.3+1.01 \mathrm{x} \\ \text { Bablok et al.: } & \mathrm{y}=-1.8+1.02 \mathrm{x}\end{array}$

d. $\alpha_{1}$-micoglobulin (radial immunodiffusion method)

linear regression:

$n=40 ; r=0.980$

$y=-1.8+1.11 x$

Bablok et al.:

e. $N$-acetyl- $\beta$ - $D$-glucosaminidase. The present method was compared with a previously published adaptation of the Noto procedure (13) to the Epos analyser, which was also compared with the manual method of Maruhn et al. (14) using nitrophenyl derivatives as substrate, with gel filtration (8).

linear regression:

Bablok et al.:

linear regression:

Bablok et al.:

f. creatinine (Jaffe kinetic, Hitachi 705, using 1:20 diluted urine samples)

linear regression:

Bablok et al.:

$$
\begin{aligned}
& \text { Epos/Maruhn } \\
& \mathrm{n}=59 ; \mathrm{r}=0.994 \\
& \mathrm{y}=0.15+0.42 \mathrm{x} \\
& \mathrm{y}=0.11+0.42 \mathrm{x} \\
& \text { Epos/Kone } \\
& \mathrm{n}=73 ; \mathrm{r}=0.999 \\
& \mathrm{y}=0.01+0.94 \mathrm{x} \\
& \mathrm{y}=0.01+0.94 \mathrm{x} \\
& \text { Hitachi } 705, \text { using } \\
& \mathrm{n}=74 ; \mathrm{r}=0.991 \\
& \mathrm{y}=0.20+0.94 \mathrm{x} \\
& \mathrm{y}=0.12+0.95 \mathrm{x}
\end{aligned}
$$



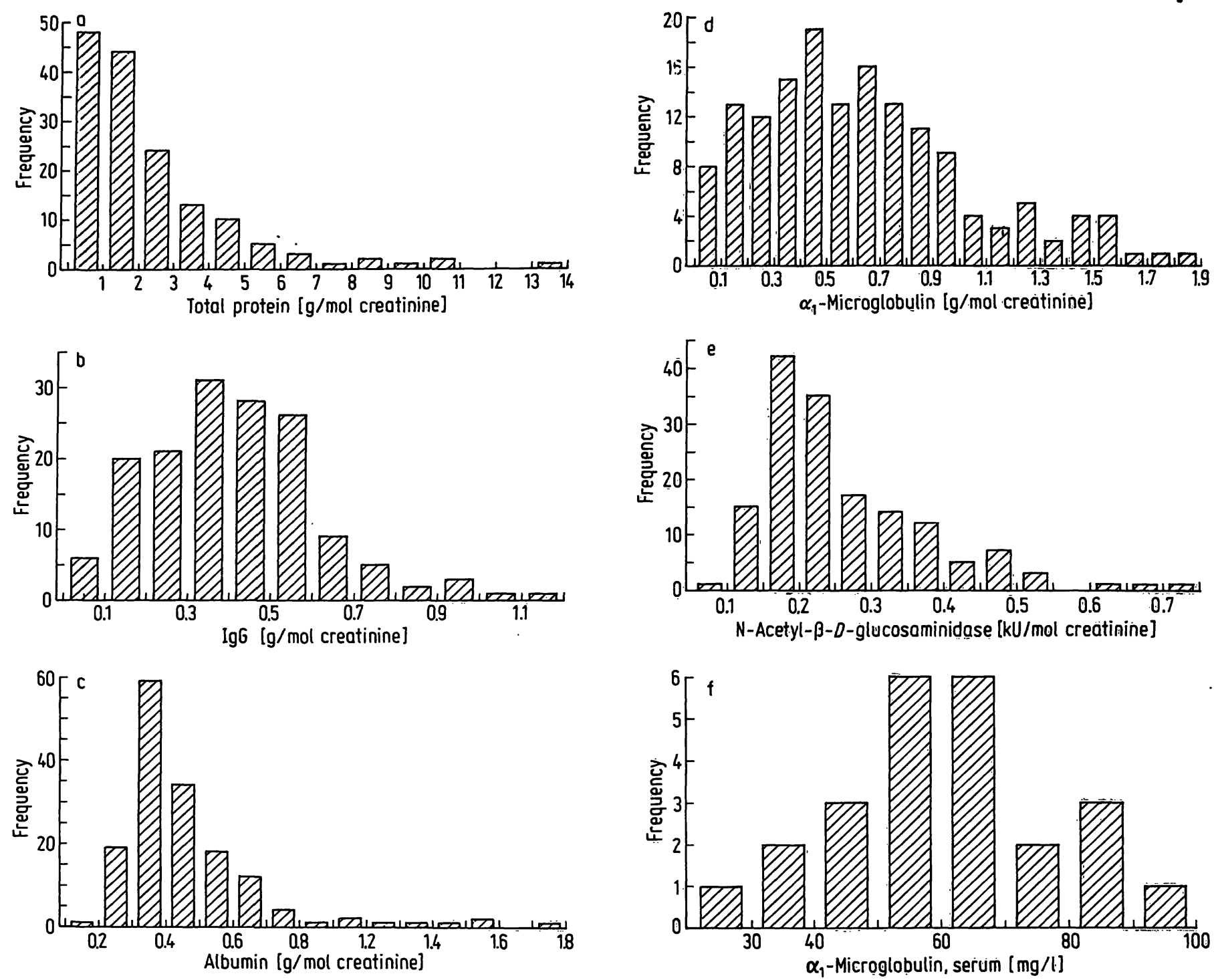

Fig. 2. Distribution of results in urines and sera from a normal population.

154 second morning urines and 31 sera from 31 normal persons (see methods for age and sex distribution) were analyzed with the procedures described in the methods section and the results expressed in relation to the creatinine concentration in the same sample.

\begin{tabular}{lccc} 
Analyte & $\mathrm{N}$ & Median & 95th percentile \\
\hline a. Total protein (g/mol creatinine) & 154 & 1.6 & 6.3 \\
b. IgG (g/mol creatinine) & 153 & 0.4 & 0.77 \\
c. Albumin (g/mol creatinine) & 154 & 0.95 & 1.34 \\
d. $\alpha_{1}$-Microglobulin (g/mol creatinine) & 154 & 0.59 & 1.49 \\
e. N-acetyl- $\beta-D$-glucosaminidase $(\mathrm{kU} / \mathrm{mol}$ creatinine) & 154 & 0.22 & 0.47 \\
f. $\alpha_{1}$-Microglobulin, serum (mg/l) & 24 & 60 & 86
\end{tabular}

$\alpha_{1}$-Microglobulin and $\mathrm{N}$-acetyl- $\beta$ - $D$-glucosaminidase activity were raised in 14 and 13 cases respectively.

The leukocyte test strip was positive in 32 urines. Nine of these urines showed no positive result outside the reference ranges in the present programme. Total protein and $\mathrm{N}$-acetyl- $\beta$ - $\dot{D}$-glucosaminidase were raised in 18 urines (56\%), albumin and $\alpha_{1}$-microglobulin in 19 cases (59\%) and IgG in $21(66 \%)$.

\section{Discussion}

The present study was performed to establish a fully automated programme for screening and differentiation of proteinuria in a routine laboratory. The analytes chosen allow the recognition of all types of glomerular and tubular proteinuria. In contrast, the test strip procedure for screening for proteinuria, although relatively specific for albumin, detects this 
Tab. 6. Comparison of excretion rates in second morning and $24 \mathrm{~h}$ urine from 13 normal persons.

\begin{tabular}{|c|c|c|c|c|c|}
\hline & \multicolumn{2}{|c|}{ Second morning urine } & \multicolumn{2}{|c|}{24 hour urine } & \multirow[t]{2}{*}{ Bias } \\
\hline & median & range & median & range & \\
\hline \multicolumn{6}{|l|}{ Total protein } \\
\hline $\begin{array}{l}\mathrm{mg} / \mathrm{l} \\
\mathrm{g} / \mathrm{mol} \text { creatinine }\end{array}$ & $\begin{array}{l}31 \\
1.7\end{array}$ & $\begin{array}{l}10-55 \\
1.1-10.9\end{array}$ & $\begin{array}{l}11 \\
<1.1\end{array}$ & $\begin{array}{l}<10-20 \\
<1.1-1.8\end{array}$ & +20 \\
\hline \multicolumn{6}{|l|}{ IgG } \\
\hline $\begin{array}{l}\mathrm{mg} / \mathrm{l} \\
\mathrm{g} / \mathrm{mol} \text { creatinine }\end{array}$ & $\begin{array}{l}5.2 \\
0.42\end{array}$ & $\begin{array}{l}2.6-11.3 \\
0.22-1.00\end{array}$ & $\begin{array}{l}3.8 \\
0.25\end{array}$ & $\begin{array}{l}1.1-10.4 \\
0.13-0.64\end{array}$ & $\begin{array}{l}+1.4 \\
+0.17\end{array}$ \\
\hline \multicolumn{6}{|l|}{ Albumin } \\
\hline $\begin{array}{l}\mathrm{mg} / \mathrm{l} \\
\mathrm{g} / \mathrm{mol} \text { creatinine }\end{array}$ & $\begin{array}{c}10.5 \\
0.65\end{array}$ & $\begin{array}{l}<4-18.4 \\
<0.45-1.11\end{array}$ & $\begin{array}{l}5.8 \\
0.53\end{array}$ & $\begin{array}{l}<4-12.1 \\
<0.45-1.05\end{array}$ & $\begin{array}{l}+4.7 \\
+0.12\end{array}$ \\
\hline \multicolumn{6}{|l|}{$\alpha_{1}$-Microglobulin } \\
\hline $\begin{array}{l}\mathrm{mg} / \mathrm{l} \\
\mathrm{g} / \mathrm{mol} \text { creatinine }\end{array}$ & $\begin{array}{c}10.2 \\
0.99\end{array}$ & $\begin{array}{l}4.5-34.8 \\
0.22-1.74\end{array}$ & $\begin{array}{l}8.2 \\
0.65\end{array}$ & $\begin{array}{l}2.4-30.4 \\
0.27-1.89\end{array}$ & $\begin{array}{l}+2.0^{*} \\
+0.34^{* *}\end{array}$ \\
\hline \multicolumn{6}{|c|}{$\mathrm{N}$-Acetyl- $\beta-D$-glucosaminidase } \\
\hline $\begin{array}{l}\mathrm{U} / 1 \\
\mathrm{kU} / \mathrm{mol} \text { creatinine }\end{array}$ & $\begin{array}{l}3.6 \\
0.25\end{array}$ & $\begin{array}{l}1.2-6.3 \\
0.11-0.48\end{array}$ & $\begin{array}{l}2.9 \\
0.28\end{array}$ & $\begin{array}{l}1.7-5.8 \\
0.18-0.40\end{array}$ & $\begin{array}{l}+0.7^{* *} \\
-0.03\end{array}$ \\
\hline $\begin{array}{l}\text { Creatinine } \\
\text { mmol/1 }\end{array}$ & 14.9 & $3.0-25.8$ & 10.9 & $6.8-16.1$ & +4.0 \\
\hline
\end{tabular}

$* \alpha=0.001$

$* * \alpha=0.05$

Excretion of the analytes was measured in second morning and $24 \mathrm{~h}$ urine samples on the same day. Statistical significance of differences (bias) was tested by the paired signed test of Wilcoxon, Mann \& Whitney (16).

protein at an excretion rate 10 times above normal $(1,3,4)$. In addition prerenal and tubular proteinuria are not detected by the protein-error-of-indicator principle $(1,4)$. The polyacrylamide gel electrophoresis technique, which separates proteins according to their relative molecular mass, was therefore propagated to detect and differentiate these different forms $(5,6,7)$. In fact when applied in a screening programme many more proteinurias were detected, primarily of the tubular type (20).

In contrast to this technique, the presently used quantitative measurement of characteristic proteins gives additional information about the degree of tubular and glomerular proteinuria. The present programme of analytes was chosen to combine the sensitivity of the electrophoretic procedure with the advantages of quantification and automation. In addition, by including the automated measurement of $\mathrm{N}$-acetyl- $\beta-D$ glucosaminidase and creatinine, the present profile yields more information than previously suggested regimes. The automated assay of $N$-acetyl- $\beta$ - $D$-glucosaminidase was proposed as a screening procedure by Tucker et al. (21).

Polyacrylamide-gel-electrophoresis seems more suitable only for the detection of prerenal proteinuria such as myoglobinuria and Bence-Jones-proteinuria
(22). Recent experience with urines of patients with monoclonal gammopathies (23) has shown that these forms can be recognized from the discrepancy between total protein and albumin, and that they simultaneously exhibit an elevated $\mathrm{N}$-acetyl- $\beta$ - $D$-glucosaminidase activity and $\alpha_{1}$-microglobulin concentration (24).

\section{Biological variation of urinary proteins}

Other investigators have reported the biological day to day variation of urinary analytes. Thus Hemmingsen \& Skaarup (25) found that albumin varied day to day by $31 \%$, IgG by $26 \%$, and lysozyme by $36 \%$. In studies on $24 \mathrm{~h}$ urines Bingham et al. (26) found intraindividual variations for urine analytes between $10.7 \%$ (creatinine) and $30.5 \%$ (sodium). For albumin, measured in urines of normal persons, Viberti et al. $(27,28)$ found a large intra-individual variation, which was only slightly less when related to creatinine. Calculation of urinary enzyme activities, in relation to creatinine reduced the intra-individual variabilities $(29,30,31)$. Our present results confirm and extend these observations. When compared with concentrations, excretion rates related to creatinine showed slightly but significantly lower biological variations. This may however limit the diagnostic value in situ- 
Tab. 7. Comparison of present analytical profile with test strip procedure for screening unselected urines.

a) Total results

\begin{tabular}{llllllllll}
$\mathrm{n}=67$ & $\begin{array}{l}\text { Protein } \\
\text { test strip }\end{array}$ & Blood & $\begin{array}{l}\text { Leuko- } \\
\text { cyte }\end{array}$ & Glucose & $\begin{array}{l}\text { Total } \\
\text { protein }\end{array}$ & IgG & $\begin{array}{l}\text { Albu- } \\
\text { min }\end{array}$ & $\begin{array}{l}\alpha_{1}-\text { Micro- } \\
\text { globulin }\end{array}$ & $\begin{array}{l}\text { N-Acetyl- } \beta-D- \\
\text { glucosaminidase }\end{array}$ \\
\hline $\begin{array}{l}\text { Positive } \\
\text { Negative }\end{array}$ & 13 & 18 & 32 & 3 & 26 & 28 & 28 & 26 & 28 \\
\hline
\end{tabular}

b) Urines with increased albumin and $\mathrm{N}$-acetyl- $\beta$ - $D$-glucosaminidase excretion

1. albumin $>2.26 \mathrm{~g} / \mathrm{mol}$ creatinine ( $20 \mathrm{mg} / \mathrm{g}$ creatinine)

\begin{tabular}{lccccc}
$\mathbf{n}=28$ & Total protein & IgG & $\begin{array}{l}\alpha_{1} \text {-Micro- } \\
\text { globulin }\end{array}$ & $\begin{array}{l}\text { N-Acetyl- } \beta-D- \\
\text { glucosaminidase }\end{array}$ & \begin{tabular}{l} 
Protein test strip \\
\hline Positive
\end{tabular} \\
Negative & 24 & 25 & 21 & 20 & 12 \\
\hline
\end{tabular}

2. $\mathrm{N}$-Acetyl- $\beta$ - $D$-glucosaminidase $>0.56 \mathrm{kU} / \mathrm{mol}$ creatinine $(5 \mathrm{U} / \mathrm{g}$ creatinine)

\begin{tabular}{lccccc}
$\mathrm{n}=28$ & Total protein & IgG & Albumin & $\alpha_{1}$-Microglobulin & Protein test strip \\
\hline Positive & 21 & 22 & 20 & 22 & 11 \\
Negative & 7 & 6 & 8 & 6 & 17 \\
\hline
\end{tabular}

\section{Combination}

albumin $>2.26 \mathrm{~g} / \mathrm{mol}$ creatinine ( $20 \mathrm{mg} / \mathrm{g}$ creatinine)

and $\mathrm{N}$-acetyl- $\beta$ - $D$-glucosaminidase $>0.56 \mathrm{kU} / \mathrm{mol}$ creatinine ( $5 \mathrm{U} / \mathrm{g}$ creatinine)

\begin{tabular}{lllllll}
$\mathbf{n}=36$ & Total protein & IgG & Albumin & $\begin{array}{l}\alpha_{1} \text {-Micro- } \\
\text { globulin }\end{array}$ & $\begin{array}{l}\text { N-Acetyl- } \beta-\dot{D}- \\
\text { glucosaminidase }\end{array}$ & $\begin{array}{c}\text { Protein test strip } \\
\text { Positive }\end{array}$ \\
Negative & 26 & 27 & 28 & 24 & 28 & 21 \\
\hline
\end{tabular}

c) Urines with positive blood and/or leukocyte test strip field

1. blood test field positive

\begin{tabular}{|c|c|c|c|c|c|}
\hline $\mathrm{n}=18$ & Total protein & $\operatorname{IgG}$ & Albumin & $\alpha_{1}$-Microglobulin & $\begin{array}{l}\text { N-Acetyl- } \beta=D \text { - } \\
\text { glucosaminidase }\end{array}$ \\
\hline $\begin{array}{l}\text { Positive } \\
\text { Negative }\end{array}$ & 16 & 17 & 16 & 14 & 13 \\
\hline Negative & 2 & 1 & 2 & 4 & 5 \\
\hline
\end{tabular}

2. leukocyte test field positive

\begin{tabular}{llllll}
$\mathrm{n}=32$ & Total protein & IgG & Albumin & $\alpha_{1}$-Microglobulin & $\begin{array}{l}N-A c e t y l-\beta-D- \\
\text { glucosaminidase }\end{array}$ \\
\hline Positive & 18 & 21 & 19 & 19 & 18 \\
Negative & 14 & 11 & 13 & 13 & 14 \\
\hline
\end{tabular}

ations where urine creatinine is highly variable, as in pediatric urines (32), athletes (Hofmann, W., Beuker, $F$. \& Guder, $W$. G. unpublished observations) and in acute renal failure (33). As expected, the intra-individual variability was much lower than the interindividual variability. Compared with the biological variation of serum parameters (34), the variability for urinary parameters was much higher. This can be expected for an open system like urine where many more physiological influences, like fluctuating filtration rates, changing reabsorption and catabolism must be considered.

Remarkably the biological variability for $\mathrm{N}$-acetyl- $\beta$ $D$-glucosaminidase was oply half of that of the other proteins. This might be explained by the fact that IgG, albumin and $\alpha_{1}$-microglobulin are filtered in varying amounts through the glomerular basal mem- 
brane. Haemodynamic factors like blood pressure and different reabsorption rates of high and low molecular weight proteins influence the excretion rates of these tested proteins (20). In contrast $\mathrm{N}$-acetyl- $\beta$ - $D$-glucosaminidase is added to the urine by the turnover of cells. This process has been shown to proceed periodically (35).

\section{Selection of sample}

For qualitative screening purposes the first morning urine is generally used, whereas $24 \mathrm{~h}$ urine sampling is suggested for quantitative urine determinations (36). With regard to urine protein and enzyme activity determination, no uniform recommendations exist in the literature $(19,27,29,35,37)$.

Our observation that second morning urine and $24 \mathrm{~h}$ urine showed no significant differences when results were related to creatinine makes it possible to substitute the $24 \mathrm{~h}$ urine for the second morning urine. This circumvents the problem of quantitative urine collection (26). The second morning urine has additional advantages because of its higher practicability in ambulatory screening. Sailer et al. (38), Gatling et al. (39) and Watts et al. (40) showed, for diabetics, that morning urine has the same diagnostic efficiency for the recognition of microalbuminuria as an overnight or twenty-four hour urine. Jung \& Schulze (30), Burchardt et al. (35) and Schulze \& Goebel (41) reported investigations on the determination of urine enzyme activities in second morning urine related to creatinine. According to their conclusion, inactivation of enzymes could be avoided and different excretion rates corrected.

Application of the present programme as a screening procedure

Application of the present programme as a screening procedure resulted in the expected higher number of positive results. These additional "positives" were mainly due to albuminuria below the detection limit of the test strip, tubular proteinurias and urines with increased $N$-acetyl- $\beta$ - $D$-glucosaminidase activity and IgG excretion. Albumin and $\mathrm{N}$-acetyl- $\beta$ - $D$-glucosaminidase, when used as the only criteria, were able to detect $97 \%$ of all urines positive in one of the analytes quantified. Therefore these two parameters seem to be sufficient for excluding clinically relevant glomerular and tubular forms of proteinuria.

From the other test strip procedures only the leukocyte test field resulted in additional positive answers, whereas more than $90 \%$ of urines with haematuria exhibited at least one result outside the reference range when the present profile was applied. As a preliminary conclusion it seems advisable to add a test for leukocytes to the present profile to exclude infectious diseases of the urinary tract.

\section{Future aspects and conclusions}

The present programme seems to be sufficiently sensitive for the detection of all clinically relevant types of glomerular and tubular proteinuria. To differentiate between prerenal and renal types of proteinuria the present concept has to be tested in special patient groups. By setting the decision limits outside the normal range, it is possible to differentiate and monitor various forms of clinical nephropathies. In addition, ratios between the measured analyte concentrations may be used diagnostically; such ratios have already beeen successfully applied in the analysis of liver diseases (42) and spinal fluid analysis (43). As long as 23 years ago, Cameron \& Blandford proposed the use of analyte ratios in urine analysis (44).

In conclusion the present programme offers the possibility of screening large numbers of urine samples by quantitative analysis with little additional to the work load. Reagent costs can be kept within the range of those for routine clinical chemistry procedures by using the present strategy.

\section{References}

1. Kutter, D. (1983) Schnelltests in der klinischen Diagnostik. 2. Aufl., UTban \& Schwarżenberg, München, Wien, Baltimore.

2. Weidemann, G. \& Guder, W. G. (1986) Harnuntersuchungen. In: Nierenkrankheiten 5. Aufl. (Sarre, H. \& Gessler, V., eds.) pp. 59-73, Thieme, Stuttgart.

3. Guder, W. G. \& Heidland, A. (1986) Urine analysis. J. Clin. Chem. Clin. Biochem. 24, 611-620.

4. Lorentz, K. \&.Weiss, T. (1986) Proteinbestimmung im Urin - Eine kritische Úbersicht. J. Clin. Chem. Clin. Biochem. $24,309-323$.

5. Boesken, W. H. (1977) Die SDS-PAA-Elektrophorese der Urinproteine: Eine Methode zur Differentialdiagnose der Nephropathien und zur Analyse extrarenaler Proteinurien. Urologe $17,140-144$.

6. Scherberich, J. E. (1986) Proteinverteilungsmuster im Harn: wertvolle Hilfe bei der Diagnostik glomerulärer und tubulärer Erkrankungen. Bioscientia Bericht Nr. 28.

7. Spieker, C. \& Lison, A. E. (1984) Polyacrylamide gel electrophoresis (PAGE). Range of possible application in renal medicine. In: Advances in Non-Invasive Nephrology (Lubec, G. \& Campese, A., eds.) pp. 195-198 John Libbey. 
8. Hallbach, J., Poppe, W. \& Guder, W. G. (1985) An automated procedure to measurc $\mathrm{N}$-acetyl- $\beta$ - $D$-glucosaminidase in urine. J. Clin. Chem. Clin. Biochem. 23, 590 (abstract).

9. Cheung, C. K., Mak, Y. T. \& Swaminathan, R. (1987) Automated trichloracetic acid precipation method for urine total protein. Ann. Clin. Biochem. 24, 140-144.

10. Hofmann, W. \& Guder, W. G. (1988) Automatisierung der quantitativen Bestimmung von Harnproteinen und Harnenzymen zur nephrologischen Stufendiagnostik. Fresenius Z. Anal. Chem. 330, 428-429.

11. Richterich, R. \& Colombo, J. P. (1978) Urinprotein, BiuretMethode. In: Klinische Chemie pp. 566-569, Karger-Verlag, Basel.

12. Hofmann, W. \& Guder, W. G. (1987) Adaptation eines immunturbidimetrischen Testes zur Albuminbestimmung im Urin an das Analysengerät Kone Progress. Ärztl. Lab. $33,229-232$.

13. Noto, A., Ogawa, Y., Mori, S., Yoshioko, M., Kitakaze, T., Hori, T., Nakamura, M. \& Miyake, T. (1983) Simple, rapid spectrophotometry of urinary $\mathrm{N}$-acetyl- $\beta-D$-glucosaminidase with use of a new chromogenic substrate. Clin. Chem. 29, 1713-1716.

14. Maruhn, D., Fuchs, I., Mues, G. \& Boche, K. D. (1976) Normal limits of urinary excretion of eleven enzymes. Clin. Chem. 22, 1567-1574.

15. Keller, H. (1986) Klinisch-chemische Labordiagnostik für die Praxis. pp. 76-90, Thieme Verlag.

16. Sachs, L. (1982) Statistische Methoden. Springer Verlag, Berlin, Heidelberg, New York.

17. Bablok, W., Passing, H., Bender, R. \& Schneider, B. (1988) A General Regression Procedure for Method Transformation. J. Clin. Chem. Clin. Biochem. 26, 783-790.

18. Hofmann, W. \& Guder, W. G. (1989) Praeanalytische und analytische Faktoren bei der Bestimmung von IgG, Albumin, $\alpha_{1}$-Mikroglobulin und Retinol-bindendem Protein im Urin mit dem Behring Nephelometer System (BNS). Lab. Med. (submitted)

19. Marubn, D. (1983) Methodische Aspekte der Harnenzymologie. Z. Ges. Inn. Med. 38, 557-564.

20. Alt, J. M., Hacke, M., von der Heyde, D. \& Stolte, H. (1983) Urinary protein excretion in interstitial and tubular kidney disease as characterized by gradient electrophoresis. Klin. Wochenschr. 61, 641-648.

21. Tucker, S. M., Boyd, P. J. R., Thompson, A. E. \& Price, R. G. (1975) Automated assay of $N$-acetyl- $\beta$-glucosaminidase in normal and pathological human urine. Clin. Chim. Acta 62, 333-339.

22. Fink, P. C., Engelke, C. \& Haeckel, R. (1988) Früherkennung von Nierenschädigungen durch die Proteinuriedifferenzierung bei Patienten mit Multiplem Myelom. Lab. Med. $12,39-50$.

23. Fateh-Moghadam, A., Schmidt, D., Hofmann, W. \& Guder, W. G. (1989) Analysis of proteinuria in patients with multiple myeloma (in preparation).

24. Cooper, E. H., Forbes, M. A., Crockson, R. A. \& MacLennan, I. C. M. (1984) Proximal renal tubular function in myelomatosis: observations in the fourth medical research council trial. J. Clin Pathol. 37, 852-858.

25. Hemmingsen, L. \& Skaarup, P. (1975) The 24-hour excretion of plasma proteins in the urine of apparently healthy subjects. Scand. J. Clin. Lab. Invest. 35, 347-353.
26. Bingham, S. A., Williams, R., Cole, T. J., Price, C. P. \& Cunnings, J. (1988) Reference values for analytes of 24-h urine collections known to be complete. Ann. Clin. Biochem. 25, 610-619.

27. Viberti, G. C., Mogensen, C. E., Keen, H., Jacobsen, F. K., Jarrett, R. J. \& Christensen, C. K. (1982) Urinary excretion of albumin in normal man: The effect of water loading. Scand. J. Clin. Lab. Invest. 42, 147-151.

28. Mogensen, C. E., Chachati, A., Christensen, C. K., Close, C. F., Deckert, T., Hommel, E., Kástrup, J., Lefebvre, P., Mathiesen, E. R., Feldt-Rasmussen, B., Schnetz, A. \& Viberti, G. C. (1985-86) Microalbuminuria: An early marker of renal involvement in diabetes. Uremia Invest. 9, 85-95.

29. Werner, M., Heilbron, D. C., Maruhn, D. \& Atoba, M. (1970) Patterns of urinary enzyme excretion in healthy subjects. Clin. Chim. Acta 29, 437-449.

30. Jung, K. \& Schulze, G. (1986) Diuresis-dependent excretion of multiple forms of renal brush-border enzymes in urine. Clin. Chim. Acta 156, 77-84.

31. Vanderlinde, R. L. (1981) Urinary enzyme measurements in the diagnosis of renal disorders. Ann. Clin. Lab. Sci. 11, $189-201$.

32. Burchardt, U. \& Miesel, B. (1977) Alaninaminopeptidaseausscheidung mit dem Harn in Abhängigkeit von Alter und Geschlecht. Zschr. Inn. Med. 32, 319-322.

33. Kristof, O. (1989) Harnproteine und Harnenzyme beim akuten Nierenversagen. Dissertation, München.

34. Keller, H. (1986) Krankheitsfrüherkennung und Entscheidungsgrenzen von klinisch-chemischen Tests. Dt. Ges. Klin. Chem. Mitt. 17, 2-8.

35. Burchardt, U., Winkler, K., Klagge, M., Balschum, D. \& Barth, A. (1988) Infradian biorhythms of enzymuria in man. J. Clin. Chem. Clin. Biochem. 26, 491-496.

36. Krieg, M., Gunßer, K. J. \& Becker, H. (1986) Vergleichende quantitative Analytik klinisch-chemischer Kenngrößen im 24-Stunden Urin und Morgenurin. J. Clin. Chem. Clin. Biochem. 24, 863-869.

37. Hutchinson, A. S., O'Reilly, D. \& MacCuish, A. C. (1988) Albumin excretion rate, albumin concentration and albu$\mathrm{min} /$ creatinine ratio compared for screening diabetics for slight albuminuria. Clin. Chem. 34, 2019-2021.

38. Sailer, N. A., Xavier, F. R., Spathis, G. S. \& Barron, J. L. (1988) Screening for microalbuminuria. Ann. Clin. Biochem. 25, supplement $99 \mathrm{~s}-100$ s.

39. Gatling, V., Knight, C. \& Hill, R. D. (1985) Screening for early diabetic nephropathy: Which sample to detect microalbuminuria? Diabetic Medicine 2, 451-455.

40. Watts, G. F., Shaw, K. M. \& Polak, A. (1986) The use of random urine to screen for microalbuminuria in the diabetic clinic. Practical Diabetes 3, 86-88.

41. Schulze, G. \& Goebel, H. (1988) Harnenzymdiagnostik ein Vorschlag zur Definition der präanalytischen Bedingungen. Z. Med. Lab. Diagn. 29, 381-386.

42. Schmidt, F. W., Schmidt, E. \& Chemnitz, G. (1984) Krankheiten der Leber. pp. 377-473, Urban \& Schwarzenberg, München, Wien, Baltimore.

43. Reiber, H. \& Felgenhauer, K. (1987) Protein transfer at the blood cerebrospinal fluid barrier and the quantitation of the humoral immune response within the central nervous system. Clin. Chim. Acta 163, 319 = 328 .

44. Cameron, J. S. \& Blandford, G. (1966) The simple assessment of selectivity in high proteinuria. Lancet $I I, 242$.

Prof. Dr. W. G. Guder

Institut für Klinische Chemie

Englschalkinger Straße 77

D-8000 München 81 